\title{
Satisfaction of Using Mobile Banking in Islamic Banks: TTF and Information Quality Perspective
}

\author{
Vero Deswanto ${ }^{1}$ \\ \{vero_deswanto@mercubuana.ac.id $\left.{ }^{1}\right\}$ \\ Universitas Mercu Buana Jakarta, Indonesia ${ }^{1}$
}

\begin{abstract}
The purpose of this paper is to evaluate the impact of Fit Technology Task (TTF) and Information Quality (QI) on User Satisfaction (US) mobile banking applications in Islamic banking in Jakarta, Indonesia. Quantitative methodology was used in this study and data was collected through a written questionnaire. The measurement items used in the operationalization of the research instruments were adopted from previous related studies. The findings show that the suitability of technology and tasks of mobile banking customers, and the quality of information about mobile banking applications are important factors that influence customer satisfaction. This research is only limited to the study of the influence of TTF and IQ and still requires further research to observe the factors that influence customer satisfaction in using mobile banking. Through this research, it is expected to be able to make a positive contribution to finance and technology, especially with the development of Fintech (financial technology) and banking technologies such as mobile banking. Practically, this research is expected to contribute to Islamic banking in Indonesia by taking into account the development of mobile banking application technology that is able to provide compatibility between technology and tasks and technology that is able to provide optimal quality information to generate customer satisfaction in using mobile banking.
\end{abstract}

Keywords: Accounting Information System, Task- Technology Fit, Mobil Banking, Information Quality.

\section{Introduction}

The development of Finance Technology (Fintech) products, encourages Islamic banks to make changes and innovations in banking operations. The ease offered by many fintech gives the public confidence to use and transact using fintech technology. Islamic banking innovation is needed to accompany technology development in Fintech services. The importance of technology adoption for Islamic banking in Indonesia by implementing digitalization as one way to improve the progress and development of Islamic banking in Indonesia, this requires the preparation of technology that is able to facilitate and provide comfort and security guarantees for customer transactions. Islamic banking in Indonesia is aware of customer needs for ease of banking services. The limited access to banking services is one of the reasons that financial technology is increasingly in demand by consumers. So, the need for the development of digitalization of Islamic banking services towards Fintech that can facilitate customers to transact through the internet network.

Kasumaningrum (2018), said that the digitalization of Islamic banking mobile banking has not been optimal due to the low level of public understanding and awareness of 
the use of Islamic bank digitalization products [1]. This is evidenced that the Islamic financial literacy index in 2016 was still in the range of 8.11 percent below the general financial literacy index which was around 29.66 percent. Likewise, with the awareness of the use of Islamic financial products, as indicated by the Islamic financial inclusion index in the same period, it was only 11.06 percent far below the national financial inclusion index which reached 67.82 percent. Technological developments encourage Islamic banking to keep up with the development of banking digitalization, one of which is mobile banking technology. The only digitalization obstacle of Islamic banking is the low level of understanding of technology and the competence of HR in developing banking technology that is capable of meeting Islamic banking needs, and this requires a considerable investment value in terms of knowledge, research and technology. OJK Representative, OJK Director of Capital Market Arrangement, Luthfy Zain said that there are many real examples of how companies that are slow to use digitalization will be left behind, and banks must innovate more because competition with Fintech is currently getting tighter (2).

The researcher interest in discussing this case is to answer how the technological aspects and aspects of mobile banking assignments give customers confidence in using mobile banking in conducting Fintech transactions. Research topics are expected to be able to provide answers to the phenomenon of technological aspects of the suitability aspects of the use of mobile banking that have an impact on the use of mobile banking in interacting with Fintech transactions. This study examines and develops from previous research, which deals with the concept of the Task Technology Fit model information system, as well as the usage model in the Delone model. Research provides empirical evidence by testing statistically to validate the integrase model. This research aims to assess and determine the effect of technological aspects and the use of technology on Fintech transactions through mobile banking in Islamic banks. Ensure whether mobile banking technology in Islamic banks works optimally in the development of the Fintech environment.

\section{Literature review}

Digitizing mobile banking to support Fintech transactions, where sharia bank customers can access all their portfolio, deposits, and financing portfolios. Mobile banking technology is one of the banking technologies currently being used by most Islamic banks in Indonesia and is of particular concern to assess whether mobile banking technology in Islamic banks works optimally in the development of the current technological environment. Through mobile banking technology, customers of Islamic banks can access account balances, pay bills, transfer funds, and do other financial services. The role of mobile banking in the development of Islamic banks has an aspect of customer interest in using Islamic banking. Digitizing sharia mobile banking that is able to connect the customer's needs to transact in fintech technology. Sharia banking investment in the development of mobile banking digitalization, to provide convenience to customers in Fintech transactions, facilitate customers in banking transactions without visiting branch offices, and offer easy access to banking services and products and other fintech products. This also allows banks to get additional benefits such as cost savings (Hoehle and Huff, 2018)[3].

Technology enables customers to transact on a mobile basis, and transact e-commerce (Kourouthanassis and Giaglis, 2012)[4]. The ability to change banking transaction technology, through mobile technology, needs to be done by banks to meet customer needs in banking 
transactions without being limited by time and place (Floh and Treiblmaier, 2015)[5]. Digitizing banks, demanding technology investment that is expected to encourage the use of Islamic banking products efficiently and effectively. The initialization of Islamic banking transactions must pay attention to the technological suitability aspects with the task of optimally using technology by customers. Ease of technology and convenience in the use of mobile banking technology to generate customer satisfaction in mobile banking transactions. Trust in adopting m-banking technology (6)

, as well as barriers to the use of technology in addition to technical barriers, is also faced with interest barriers related to the age and social status of customers using technology (Venkatesh, Morris, and Ackerman, 2000; Putra, 2012)[7], gender influence (Riquelme and Rios, 2010)[8].

\subsection{Task Technology Fit in Mobile Banking}

Goodhue and Thompson (1995), said that the TTF model is a model that explains that the suitability of technology to the tasks of information system users has an impact on information system utilization. Characteristics of technology, task characteristics will have a positive impact on the TTF and have a positive impact on user performance. The relation to Islamic banks mobile banking, the suitability of technology with the task of mobile banking users will optimize and increase the use of banking mobile banking. User behavior in transacting through mobile banking is influenced by the results of technology performance in meeting the needs of the customer, Dishaw and Strong (1999), find that the TTF influences user behavior in the use of IT and also stipulates that the TTF will affect the performance of individual users. This is also conveyed by Goodhue and Thompson (1995), that technology will be used when the technology affects the performance of individuals in accordance with the requirements of their duties. The TTF model is a model that explains that the suitability of technology to the tasks of information system users has an impact on information system utilization. Characteristics of technology, task characteristics will have a positive impact on the TTF and have a positive impact on user performance (Goodhue and Thompson,1995)[9].

The TTF model argues that m-banking for a high TTF level will encourage the use of mbanking, and conversely, a lower level of compatibility will reduce the user's intention to adopt m-banking (Liu, Lee, and Chen, 2011)[11]. TTF is directly and positively influenced by the user's attitude towards technology on individual performance. When the TTF is considered useful and is an increase in individual performance (Compeau and Higgins, 2006 ; and Davis, 1989)[12][13]. This study aims to see the suitability of technological aspects with the task aspects of Islamic banking mobile banking technology. This is to ensure that Islamic banking mobile banking can be used by customers if, and only if, functions are offered to end-user support (Fit) end-user tasks (Zhou, Lu, and Wang, 2010; Goodhue and Thompson,1995; and Davis, 1989)[14][9][13]. In addition, this study also aims to determine the impact of information quality on (15) success models related to the level of acceptance of mobile banking users in Islamic banking.

\subsection{Information Quality in Mobile Banking}

Quality information as basic information management in strategy design, decision making and decision making. Information generated by mobile banking, as part of the decisions of banking customers in carrying out the control function, conducts an independent and objective assessment. The importance of quality information and the usefulness of mobile 
banking that customers feel, this has caused some studies to incorporate information quality as a factor in the successful implementation of mobile banking. The size used for information quality is accuracy, completeness, relevance, content requirements, and timeliness of information. Bharati and Chaudhury (2004)[16], stated that the use of Mobile banking by sharia banking customers is influenced by customer satisfaction in its use. Zhai and Wang (2016)[17], stated that the higher the quality of information, the stronger the governance. The quality of accounting information can optimize investment choices, which complement and strengthen governance functions. Business development is supported by the use of information technology, which interacts with information systems through the process of collecting, processing, storing and using data as useful information (18). Fung et al. (1999)[19], said that the more trust customers have, the more the quality of information and interface design can affect customer satisfaction.

\subsection{Mobile Banking User Satisfaction}

The success of the use of Islamic banking mobile banking is shown by customer satisfaction in conducting transactions through mobile banking, the ease and suitability of technology and information provided by the mobile banking application. Satisfaction of the use of mobile banking as a general measure of the success of the banking information system that has been tested based on established standard instruments (Zviran and Erlich 2003; and Doll et al. 2004)[20][21]. Islamic banking assesses customer satisfaction in the use of mobile banking applications as an important element of consumer retention which leads to long-term relationships of companies that are successful with consumers (22).

Kahneman and Miller (1986)[23], stated that the satisfaction of using the application was not only assessed from the experience of using the product in this case overall mobile banking, but also the use of satisfaction that was shown from the results of the performance level, as well as inexperienced user satisfaction. Banking support for producing mobile banking products that can provide important variables in system analysis and design in assessing the success and effectiveness of information systems, the success of decision support systems and the success of automation, and information systems utility in decision making (Zviran and Erlich 2003)[20].

\section{Research Model, Hypotheses, and Methodology}

\subsection{Research Model}

The research in this paper is conveyed through a structure created using two information system models namely TTF (Goodhue - model) model and information system success model (Delone mc lean - model). We evaluate and study the literature for m-banking and explain the TTF theory and models, and also the mobile banking literature in the success of SI. The study presented the research design, conclusions, and results. Finally, it is discussed, including the implications for the theory and practice of m-banking adoption, and further research that might be approved.

The introduction of the TTF model and the success of information systems, is done by a combination of technological suitability aspects and tasks with information quality to see and measure the influence of these two variables on user satisfaction in using mobile banking in 
Islamic banks. In Figure 1 shows the research model that will be examined and reviewed in this paper. This research integrates two information system models between the DMIS Model and TTF Model, it aims to get more aspects of the influence of compatibility between technological characteristics and task characteristics, as well as the influence of information quality in influencing satisfaction of Islamic bank customers in using mobile banking applications.

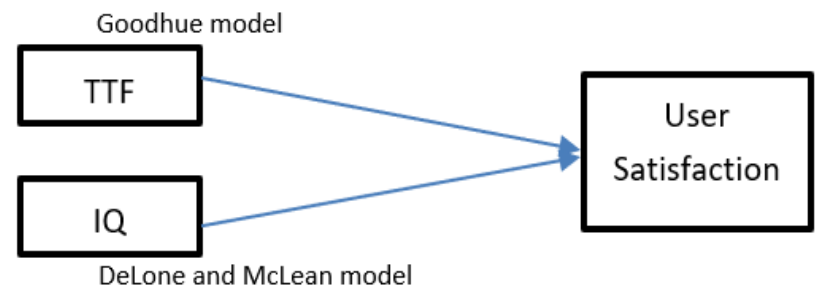

Fig. 1. Research Model

\subsection{Hypotheses}

The TTF model analyzes the suitability of technological aspects that support the activity of application users in carrying out their tasks, the prerequisites for fulfilling technology to task support show the ability of technology to produce application performance optimally. Goodhue and Thompson (1995)[9], explained that the TTF conformity model is one of the behavioral theories used to assess the process of adoption of information technology by end users and Parkes (2013)[24] explains that task-technology fit is the extent to which the complexity of the tasks carried out in accordance with the guidelines of decisions given by technology. The TTF model uses a clearly rational approach assuming that users choose to use information technology that gives them benefits (such as improving job performance) regardless of the user's attitude towards information technology (Dishaw and Strong 1999)[10]. The TTF model states that information technology will be used if and only if functions and benefits are provided to support user activity. Goodhue and Thompson (1995)[9], stated that the 4 main constructs in the TTF are:

1. Characteristics of Tasks,

2. Characteristics of Technology that affect the third construct, i.e.

3. Fit-Duty Technology, as well as TTFs have additional constructs namely

4. Individual Ability. Individual abilities are usually associated with the use of information technology.

This study examines TTF variables, gives questions as TTF indicators on questionnaires to sample respondents, which were adopted from the research of Lin and Huang (2008)[25], there are:

1. Level of suitability of service technology and mobile banking applications in providing banking services

2. Level of suitability of account management / management in mobile banking

3. Level of conformity and timeliness in the use of mobile banking

4. Overall assessment of the mobile banking application, has met the needs of customers on a technology and usage basis

In this study the researchers tested the effect of TTF on mobile banking user satisfaction

by testing the impact of technology and assignments in testing technology application 
capabilities, ensuring the quality of mobile banking services according to time, accuracy of transaction value and time, and good service capabilities in general. TTF is directly and positively influenced by the user's attitude towards technology on individual performance. When the TTF is considered useful and is an increase in individual performance, with the hypothesis of the study:

\section{H1: TTF positively affects the satisfaction of using mobile banking.}

The TTF believes that IT will be used when influencing individual performance to the extent that technological options "fit" with the requirements of their duties. IT also affects the task process, which allows end users to choose technology based on it Goodhue and Thompson (1995). TTF is directly and positively influenced by the user's attitude towards technology on individual performance. When the TTF is considered useful and is an improvement in individual performance (Compeau and Higgins, 2006 ; and Davis, 1989)[12][13], this highlights the importance of growing dependence on technology.

Assessment and measurement of the effect of information quality on customer satisfaction of Islamic banks on mobile banking applications, by giving questionnaire questions in connection with information provided by mobile banking applications, by adopting research from (Kim, Shin, and Lee, 2009; Bharati and Chaudhury, 2004; Fung et al. 1999; and Johnson and Misic 1999)[6][16][19][26], are :

1. Mobile banking will provide accurate information

2. Mobile banking will provide complete information

3. Mobile banking will provide relevant information about transactions

4. Mobile banking will provide precise information

5. Mobile banking will provide timely information about transactions

The quality of information in mobile banking can optimize mobile banking usage in customer transactions. Quality accounting information is produced from a quality information system. The inaccuracy of information in mobile banking is a risk that can lead to banking transactions. The quality of information, as assessed by customers, usually affects their satisfaction (Kim, Shin, and Lee, 2009; Bharati and Chaudhury, 2004; Fung et al. 1999; and Johnson and Misic 1999)[6][16][19][26]. Customer perception about the value of information systems to determine the quality of information. Information on important parts in the utilization of mobile banking as an integral part of satisfaction. The quality of information in this study with the hypothesis:

H2: The quality of mobile banking information will contribute positively to the satisfaction of mobile banking users.

The suitability of technology and assignments in mobile banking and good quality information affect customer satisfaction in using mobile banking. Researchers in this study did not examine the level of customer trust, where trust is the main element for customer satisfaction with mobile banking. User satisfaction is a common measure of IS success, which has been developed and tested by several standard instruments (Zviran and Erlich 2003; and Doll et al. 2004)[20][21]. Satisfaction has been used to assess the success and effectiveness of SI, the success of decision support systems, the success of office automation and SI utility in decision making. The indicator asked in the questionnaire with respect to customer satisfaction in the use of mobile banking adopted the research of (Anderson and Sullivan, 2008; and Kohli, Devaraj, Mahmood, 2017)[27][28], as follows: 
1. Recommend mobile banking to others

2. The right decision to use mobile banking

3. The way it is done by mobile banking for outgoing transactions

4. I receive from mobile banking services

5. Overall satisfaction with mobile banking

\subsection{Methodology}

This research was conducted on customers of the same Islamic bank, so that members of the population are homogeneous. This study uses a simple random sampling method as a technique to get samples that are directly carried out on the sampling unit. The study was conducted by providing a questionnaire containing questions related to research indicators to 220 BRI Syariah bank mobile banking customers in Jakarta, Indonesia. Arikunto (2013), states that the questionnaire is a written statement used to obtain information from respondents [29], and according to Sugiyono (2013) explains that the questionnaire is a technique of data collection carried out by giving a set of questions or written statements to respondents to answer [30]. Determination of the submission of questionnaires is referred to customers with geographical boundaries and ages 25 to 50 years, with the lowest educational background being a diploma.

This research was conducted by using the PLS SEM Analysis tool. SEM with PLS is used when the purpose of research is to predict and develop theories. This is in contrast to covariant-based SEM aimed at testing existing theories and confirmation. Besides that, PLS SEM is also used to predict endogenous latent variables or identify the main variables if research is exploratory research or the expansion of an existing structural theory. The results of the research analysis will explain the form and value of the relationship between variables, as the basis for the researcher to explain the synthesis of research results on the tested variables, answer the hypothesis from the formulation of the problem that has been prepared.

\section{Results and Discussion}

\subsection{Model Structure Testing}

Testing with PLS starts with testing the measurement model to test construct validity and instrument reliability. Validity test is done to measure the ability of research instruments what should be measured (Khalid, Hilman, 2012)[31]. The test of construct validity in PLS was carried out through convergent validity, discriminant validity and average extracted (AVE) tests. Reliability tests are used to measure the consistency of measuring instruments in measuring concepts or can also be used to measure the consistency of respondents in answering instruments. The instrument is said to be reliable if a person's answer to a statement is consistent or stable over time. Reliability tests in PLS can use the reliability composite method and Cronbach's alpha.

Outer loadings (measurement model) results or convergent validity are used to test the unidimensionality of each construct. According to Chinn (1998)[32], the indicator value of loading factors that are greater or equal to 0.5 can be said to be valid. The results of testing the questionnaire data of this study indicate that the average variable has an outer loading value above 0.5 which indicates the validity of the data relationship. The structural model was 
evaluated using R-square for the dependent construct, the Stone-Geisser Q-square test for predictive relevance, and the $t$ test and the significance of the coefficients of structural path parameters. Changes in the value of $\mathrm{R} 2$ can be used to assess the effect of certain independent latent variables on dependent latent variables whether they have substantive effects (33). R2 results are 0.67; 0.33; and 0.19 indicates that the models are "good", "moderate", and "weak" (Chin, 1998)[32].

This study shows that the R2 value is 0.734 which identifies this research model as a "good" model to show the results of the research hypothesis. Data reliability testing is done by composite reliability. Chin W (1998)[32] said that "The unidimensionality of the variables may be assessed by using composite reliability (should be> 0.7)". Noting the results of Composite Reliability above, the overall test results are above 0.70 , it can be stated that TTF, IQ and US variables are reliable and reliable and can be used to test hypotheses. The level of consistency of the respondent's answers is shown by Cronbach alpha, namely the level of consistency of the respondent's answers in one latent variable, with the TTF results $(0.527)$, IQ (0.723) and US (0.63).

\subsection{Hypothesis Testing}

In general, the explanatory research method is a method approach using PLS. This is because in this method there is a hypothesis test. Testing hypotheses can be seen from the value of t-statistics and probability values. To test the hypothesis using statistical values, for alpha $5 \%$ the t-statistical value used is 1.96 . So the acceptance / rejection criteria Hypothesis is $\mathrm{Ha}$ accepted and $\mathrm{H} 0$ rejected when $\mathrm{t}$-statistic $>1.96$. To reject / accept the hypothesis using probability then $\mathrm{Ha}$ is accepted if the value is $\mathrm{p}<0.05$. This study produces statistical calculations with t-statistic level> 1.96, are:

Table 1. T_Statistik

\begin{tabular}{|l|l|}
\hline & T_Statistic \\
\hline TTF --> US & 1,996 \\
\hline IQ --> US & 2,110 \\
\hline
\end{tabular}

With the relationship between the model structure in the image, as follows:

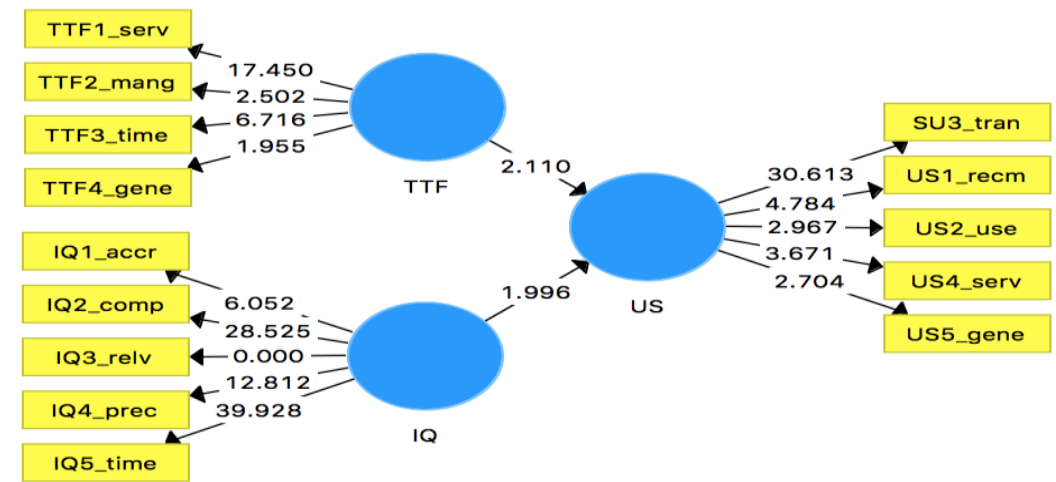


Fig. 2. Relationship of Effect of Model Structure

So that from the results of the statistical analysis it can be concluded that the hypothesis of the research proves that: TTF and IQ are related and have a positive effect on the satisfaction of mobile banking customers.

\section{Conclusion}

Technological developments have changed the pattern of banking transactions, including sharia banks that have followed technological developments to provide optimal banking transaction services to their customers. Mobile banking is a banking development that is used by Islamic banking to provide easy banking services to customers. This research attempts to provide an explanation of the factors that influence customer satisfaction in using the mobile banking application. The factors observed in this study integrated the TTF model and the Delone MC lean model. From the test sample shows the influence of TTF, IQ and the existence of significant relationships to US.

Therefore, the need for technological suitability and the task of using mobile banking and high-quality mobile information that can provide customer satisfaction in using mobile banking, especially for sharia bank customers. Overall, our research confirms the importance of the impact of TTF and the quality of information on the use and performance of m-banking individuals.

\section{References}

1. Kasumaningrum Y. Digitalisasi Kunci Penting Bagi Perbankan Syariah. pikiran rakyat. 2018 Sep;

2. Young V. Perbankan Harus Bisa Berinovasi Dengan Teknologi. bsmi. 2018;

3. Hoehle H, Huff S. Advancing Task-Technology Fit Theory: A formative measurement approach to determining task-channel fit for electronic banking channels. In: Information Systems Foundations: Theory Building in Information Systems. 2018.

4. Kourouthanassis PE, Giaglis GM. Introduction to the Special Issue Mobile Commerce: The Past, Present, and Future of Mobile Commerce Research. Int J Electron Commer. 2012;

5. Floh A, Treiblmaier H. What Keeps the E-Banking Customer Loyal? A Multigroup Analysis of the Moderating Role of Consumer Characteristics on E-Loyalty in the Financial Service Industry. SSRN. 2015.

6. Kim G, Shin B, Lee HG. Understanding dynamics between initial trust and usage intentions of mobile banking. Inf Syst J. 2009;

7. Venkatesh V, Morris MG, Ackerman PL. A longitudinal field investigation of gender differences in individual technology adoption decision-making processes. Organ Behav Hum Decis Process. 2000;83(1):33-60.

8. Riquelme HE, Rios RE. The moderating effect of gender in the adoption of mobile banking. Int J Bank Mark. 2010;

9. Goodhue D, Thompson R. Task-Technology Fit and Individual Performance. MIS Q. 1995;19(2):213-36. 
10. Dishaw MT, Strong DM. Extending the technology acceptance model with tasktechnology fit constructs. Inf Manag. 1999;36(1):9-21.

11. Liu Y, Lee Y, Chen ANK. Evaluating the effects of task-individual-technology fit in multi-DSS models context: A two-phase view. Decis Support Syst. 2011;

12. Compeau DR, Higgins CA. Computer Self-Efficacy: Development of a Measure and Initial Test. MIS Q. 2006;

13. Davis FD. Perceived Usefulness, Perceived Ease of Use, and User Acceptance of Information Technology. MIS Q [Internet]. 1989 [cited 2018 Jul 4];13(3):319-40. Available from: http://links.jstor.org/sici?sici=02767783\%28198909\%2913\%3A3\%3C319\%3APUPEOU\%3E2.0.CO\%3B2-E

14. Zhou T, Lu Y, Wang B. Integrating TTF and UTAUT to explain mobile banking user adoption. Comput Human Behav. 2010;26(4):760-7.

15. DeLone WH, McLean ER. Information systems success: The quest for the dependent variable. Inf Syst Res. 1992;3(1):60-95.

16. Bharati $\mathrm{P}$, Chaudhury A. An empirical investigation of decision-making satisfaction in web-based decision support systems. Decis Support Syst. 2004;

17. Zhai J, Wang Y. Accounting information quality, governance efficiency and capital investment choice. China J Account Res. 2016;

18. Mulyani, S.; Hassan, R; Anugrah F. The Critical Success Factors for the Use of Information Systems and its Impact on the Organizational Performance. Int Bus Manag. 2016;

19. Fung R, Lee M, K Fung RK, Kong H, O Lee MK. EC-Trust (Trust in Electronic Commerce): Exploring the Antecedent Factors. In: Association for Information Systems. 1999.

20. Zviran M, Erlich Z. Communications of the Association for Information Systems Measuring IS User Satisfaction: Review and Implications MEASURING IS USER SATISFACTION: REVIEW AND IMPLICATIONS. Commun Assoc Inf Syst. 2003;

21. Doll WJ, Deng X, Raghunathan TS, Torkzadeh G, Xia W. The meaning and measurement of user satisfaction: A multigroup invariance analysis of the end-user computing satisfaction instrument. J Manag Inf Syst. 2004;

22. Hennig-Thurau T, Klee A. The impact of customer satisfaction and relationship quality on customer retention: A critical reassessment and model development. Psychol Mark. 1997;

23. Kahneman D, Miller DT. Norm Theory. Comparing Reality to Its Alternatives. Psychol Rev. 1986;

24. Parkes A. The effect of task-individual-technology fit on user attitude and performance: An experimental investigation. Decis Support Syst. 2013;54(2):9971009.

25. Lin TC, Huang CC. Understanding knowledge management system usage antecedents: An integration of social cognitive theory and task technology fit. Inf Manag. 2008;45(6):410-7.

26. Johnson KL, Misic MM. Benchmarking: A tool for Web site evaluation and improvement. Internet Res. 1999;

27. Anderson EW, Sullivan MW. The Antecedents and Consequences of Customer Satisfaction for Firms. Mark Sci. 2008;

28. KOHLI R, DEVARAJ S, MAHMOOD MA. Understanding Determinants of Online Consumer Satisfaction: A Decision Process Perspective. J Manag Inf Syst. 2017;

29. Arikunto. Metodologi Penelitian, Suatu Pengantar Pendidikan. Rineka Cipta, Jakarta. 
2013.

30. Sugiyono. Metode Penelitian Manajemen. Alfabeta. 2013;

31. Khalid K, Hilman H, M. DK. Get Along With Quantitative Research Process. Int J Res Manag. 2012;

32. Chinn WW. The Partial Least Squares Approach to Structural Equation Modelling. Mod Methods Bus Res. 1998;

33. F. Hair Jr J, Sarstedt M, Hopkins L, G. Kuppelwieser V. Partial least squares structural equation modeling (PLS-SEM). Eur Bus Rev. 2014; 